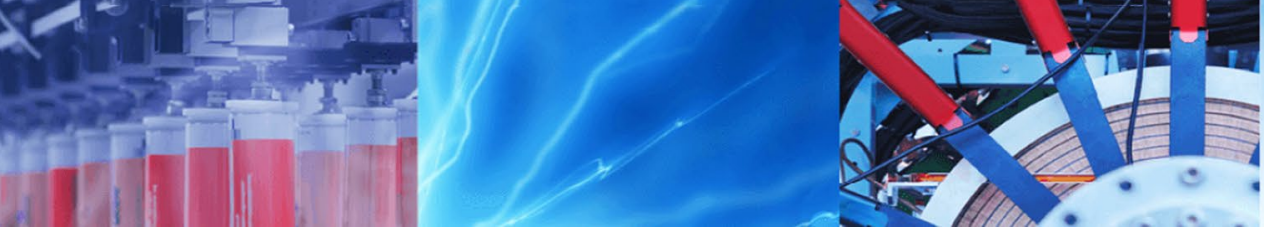

Research Article

\title{
Size-dependent catalytic property of gold nanoparticle mediated by Justicia adhatoda leaf extract
}

\author{
D. Latha ${ }^{1} \cdot$ P. Prabu ${ }^{3} \cdot$ G. Gnanamoorthy ${ }^{1} \cdot$ S. Munusamy ${ }^{1} \cdot$ S. Sampurnam ${ }^{1} \cdot$ C. Arulvasu ${ }^{2}$ - V. Narayanan ${ }^{1}$
}

(c) Springer Nature Switzerland AG 2018

\begin{abstract}
In this contribution, we demonstrate the synthesis of gold nanoparticles (AuNPs) using an entirely green chemistry process. Justicia adhatoda leaf extract used as a bioreductant for the synthesis of AuNPs and its particle sizes are controlled by altering the concentration of metal salt. The optical and morphological properties were studied. We report on the synthesis of stable spherical, well-dispersed colloidal AuNPs (27.1, 33.3 and $46.8 \mathrm{~nm}$ ) by efficient reducing agents with its mechanisms. The X-ray diffraction analysis also confirmed the obtained sizes of AuNPs with its crystallite size (20.2, 40.1 and $40.3 \mathrm{~nm}$ ). Catalytic activity of fabricated AuNPs are also examined on the degradation of organic dyes.
\end{abstract}

Keywords J. adhatoda . AuNPs . Catalytic degradation $\cdot$ Methylene blue and Congo red

\section{Introduction}

Metallic nanoparticles have occupied an important place in the field of nanoscience due to their intriguing chemical, optical, electronic properties and etc. Metallic nanoparticles are synthesized by using reducing, protective and stabilizing agents. Such kind of agents are highly toxic, flammable, may adsorb on the surface of nanoparticles and are also unfavorable in their applications [1, 2]. Due to these confines, the researchers more concentrate on green approach for synthesis of nanoparticles. Several biological systems are existing for synthesis of metallic nanoparticles like as microbes, fungi, and plant materials. Recently, nanoparticles (silver, gold, copper, platinum, palladium etc.,) have been synthesized by using plants. This is due to large scale process, rapid synthesis and also produce more stable nanoparticles compare with other microorganisms. The development of green chemistry has three important factors, they are suitable solvent, ecofriendly reducing agent and non-toxic chemicals are used in synthesis of nanoparticles [3, 4]. Among various metallic nanoparticles, researchers have more interest on gold nanoparticles (AuNPs) which is due to its unique properties, tunable SPR and applications [5].

Colloidal gold is a sol that exerted curative properties for several diseases [6]. Approximately 5.02 billion tons of gold produced by Philippines and ranked third in the world [7]. Gold nanoparticles have more commercial applications in various biomedical fields. Synthesized AuNPs have lot of applications like catalysis, cancer therapeutics, optical molecular sensing, electronics, optoelectronics, photonics diagnostic, drug delivery, biomedical sensing and imaging $[8,9]$. Upon interacting with light, excited free electrons of AuNPs directly state to collective oscillation called as a strange Surface Plasmon Resonance (SPR) phenomenon [10,11]. It can be tuned to different size or shape of the AuNPs, which cause the extensive investigation [12]. Various plant materials are used for synthesis of AuNPs such as Magnolia kobus \& Diopyros kaki [13], Acacia nilotica [14], Dillenia indica [15], Edible mushroom [16] and Cinnamomum zeylanicum [17].

\footnotetext{
$\varangle$ V. Narayanan, vnnara@yahoo.co.in | 'Department of Inorganic Chemistry, University of Madras, Guindy Campus, Chennai 600025 , India. ${ }^{2}$ Department of Zoology, University of Madras, Guindy Campus, Chennai, Tamilnadu 600025 , India. ${ }^{3}$ Department of Zoology, Pachaiyappa's College for Men, Kanchipuram, Tamilnadu 631 501, India.
} 
In this study, we have examined the synthesis of AuNPs using medicinal plant Justicia adhatoda leaf extract, belongs to Acantheceae family. Phytochemical components of the leaf contain phenols, tannins, alkaloids, anthraquinones, saponins, flavonoids and reducing sugars, vasicine, vasicinone alkaloid and quinazoline [18-20]. The leaves of J. adhatoda contains considerable amount of alkaloids, flavonoids, phenols, proteins and carbohydrates (reducing sugar). These bioactive secondary metabolites are associated with their medicinal applications.

Pollution caused by heavy metals and dyes from industrial effluents are the chief origin of environmental pollution. In recent, more than 10,000 of different commercial dyes and pigments exist and about $7 \times 10^{5}$ tones are produced annually in worldwide [21-23]. It is expected that $10-15 \%$ of dye is lost during the dyeing process from the effluent. Dyes are broadly used in various industries like textile, color photography, pharmaceutical, food, cosmetics, paper, plastics and other industries [24]. They are using dye for coloring their products and discharge the effluents into water bodies. Such contaminated water is harmful to living organisms, in particularly Methylene blue and Congo red dye, it causes serious problem to the ecosystem $[25,26]$. Methylene blue is a cationic dye and it is a heterocyclic aromatic compound $\left(\mathrm{C}_{16} \mathrm{H}_{18} \mathrm{~N}_{3} \mathrm{SCl}\right)$. Methylene blue can cause permanent injury to eyes, nausea, vomiting, diarrhea, skin irritation and severe serotonin toxicity $[27,28]$. Congo red is a heterocyclic aromatic compound $\left(\mathrm{C}_{32} \mathrm{H}_{22} \mathrm{~N}_{6} \mathrm{Na}_{2} \mathrm{O}_{6} \mathrm{~S}_{2}\right)$. It is a brownish-red crystal dye. It is chemically called as sodium salt of benzidine diazo-bis-1-naphthylamine-4-sulfonic acid. Congo red is a water soluble, highly stable and resistant to degrade. Congo red is a carcinogenic and cause irritation in skin, eye, gastrointestine and also cause blood clotting, allergic reactions and respiratory problems $[29,30]$. Numerous technologies and methods have been progressed for the removal of dyes from the industrial effluent. Various conventional methods existing such as coagulation, flocculation [31], ozonation [32], electrochemical method [33], fungal decolonization [34] adsorption on activated carbon [35-38], ultrafiltration and reverse osmosis are already in practice. These methods are costly, unsuccessful one and it cannot be effectively treated in broad range. Therefore, removal of these dyes are an important one, without using any other toxic chemicals. In recent decades, nano catalysts are attractive one to remove dyes from the industrial effluent. The nano catalyst is biocompatible, ecofriendly and facile route which is used to remove the dyes. Based on the above, the present study was focused on green synthesized AuNPs to evaluate their responsibility to degrade the dyes. We report on synthesize of stable AuNPs using leaf extract of $J$. adhatoda and project their size dependent catalytic activity in dye degradation (Congo red and Methylene blue) process.

\section{Methodology}

\subsection{Chemicals}

$\mathrm{HAuCl}_{4} \cdot 3 \mathrm{H}_{2} \mathrm{O}$ (99.9\%), Congo red, Methylene blue, and Sodium borohydride were obtained from Sigma-Aldrich.

\subsection{Preparation of aqueous leaf extract}

The leaf of Justicia adhatoda was collected from Cumbum valley, Tamil Nadu, India and it is identified by experts. The leaves were washed with DD water three times to remove the dust particles and dried (shade, dry) for 10-14 days and ground into coarse powder. The coarse powder was refluxed at $80^{\circ} \mathrm{C}$ for $20 \mathrm{~min}$ in a $250 \mathrm{~mL}$ Erlenmeyer flask containing $100 \mathrm{~mL}$ of DD water. After cooling, the extract was filtered through Whatman no. 1 filter paper and was kept in refrigerator for further use.

\subsection{Synthesis of AuNPs}

For synthesis of AuNPs, $1 \mathrm{~mL}$ aqueous extract was added to $7 \mathrm{~mL}$ of $\mathrm{HAuCl}_{4} \cdot 3 \mathrm{H}_{2} \mathrm{O}(1 \mathrm{mM})$ with constant stirring for $10 \mathrm{~min}$. The color of the reaction mixture changes from pale yellow to ruby red indicates the formation of gold nanoparticles due to the reduction of $\mathrm{Au}^{3+}$ to $\mathrm{Au}^{0}$, no precipitate was found. The synthesized gold nanoparticles were confirmed for the further characterizations.

\subsubsection{Effect of metal ion concentration}

One $\mathrm{mL}$ leaf extract was added to $7 \mathrm{~mL}$ of three different concentrations $(0.5,1.0$ and $1.5 \mathrm{mM})$ of $\mathrm{HAuCl}_{4}$, and synthesized AuNPs are labeled as $\mathrm{a}_{1}, \mathrm{a}_{2}$ and $\mathrm{a}_{3}$ respectively. The reduction and formation of AuNPs were monitored by using UV-Vis spectrophotometer.

\subsubsection{Effect of different quantities of leaf extract on formation of AuNPs}

Gold nanoparticles (AuNPs) were prepared by adding 1,2 and $3 \mathrm{~mL}$ leaf extract of J. adhatoda with $7 \mathrm{~mL}$ of $\mathrm{HAuCl}_{4} \cdot 3 \mathrm{H}_{2} \mathrm{O}(1 \mathrm{mM})$ independently, immediate pink-ruby red color was observed. The formation of AuNPs was monitored by UV-Vis spectrophotometer. 


\subsection{Characterization of AuNPs}

The formation of the gold nanoparticles was recorded in the range of 700-400 $\mathrm{nm}$ is using UV-Visible spectrophotometer (Perkin Elmer Lambda-45). The size and shape of the nanoparticles were analyzed from SEM and TEM (Hitachi and TEM-JEOL model 1200EX) analyzer along with EDX operating at $200 \mathrm{kV}$. XRD analysis of the AuNPs was performed on Powder X-Ray Diffractometer (EnrafNonius (AD-4), operating at a voltage of $40 \mathrm{kV}$ with $\mathrm{Cu} \mathrm{Ka}$ $(\lambda=1.54 \AA$ A $)$ radiation.

\subsection{Catalytic studies}

\subsubsection{Catalytic activity of Congo red degradation using AuNPs}

The catalytic activity of AuNPs was evaluated against Congo red dye as a substrate in the presence of $\mathrm{NaBH}_{4}$. For catalytic degradation, $1 \mathrm{~mL}$ of Congo red $(1 \mathrm{mM}$ ) diluted with $10 \mathrm{~mL}$ of DD water and then $1 \mathrm{~mL}$ of freshly prepared $\mathrm{NaBH}_{4}(0.1$ and $0.2 \mathrm{M})$ was added respectively [39]. Sizedependent work was done by the addition of $500 \mu \mathrm{L} \mathrm{col-}$ loidal AuNPs $\left(a_{1}, a_{2}\right.$ and $\left.a_{3}\right)$ with the mixture in UV light. The color of the samples gradually changed from deep red to colorless.

The catalytic activity of synthesized AuNPs was assessed against Methylene blue dye as a substrate in the presence of $\mathrm{NaBH}_{4}$. In a typical assay, $1 \mathrm{~mL}$ of Methylene blue $(1 \mathrm{mM})$ diluted with $10 \mathrm{~mL}$ DD water and then added to $1 \mathrm{~mL}$ of freshly prepared $\mathrm{NaBH}_{4}[39,40]$. Two blank samples were prepared by various concentrations of $\mathrm{NaBH}_{4}(0.1$ and
$0.2 \mathrm{M})$. The above procedures were repeated for the addition of $\mathrm{a}_{1}, \mathrm{a}_{2}$ and $\mathrm{a}_{3}$ of samples $(500 \mu \mathrm{L})$ with Methylene blue in the presence of $\mathrm{NaBH}_{4}$ separately. Finally, color changed into leuko Methylene blue color.

\section{Results and discussion}

Justicia adhatoda act as a biological reductor, to reduce gold chloride ions. The leaf of $J$. adhatoda constitutes water (15.3\%), proteins (6.5\%) and reducing sugar (16.4\%) (D-glucoside, D-galactose, $\beta$-glucoside-galactose, $\beta$-sitosterol-Dglucoside) [19]. During aqueous extract preparation, the reducing sugar broke down into smaller monosaccharide (glucose) unit exposing extra-CHO group [41]. The reducing activity of aldehyde group (-CHO) has been exploited by Tollens test, in which silver ions are reduced [42]. Similarly, the aldehyde group has reduced the gold ions into AuNPs. Maximum number of aldehyde group behave as a reducing agent for gold chloride ions [43].

\subsection{Justicia adhatoda extract as a reducing agent for Au NPs}

The possible redox reaction between gold ions and D-glucose has shown in schematic diagram (Fig. 1). It is continuously undergo nucleophillic substitution reaction, where $\mathrm{O}-\mathrm{H}$ radicals present in the sixth carbon of glucose unit. First of all, $\mathrm{Au}^{3+}$ ions gets attached with the oxygen of the aldehyde group present in glucose of aqueous extract, this is because of its free electrons. Due to instability of the carbon atom in the presence of $\mathrm{O}-\mathrm{H}$, those electrons gets
Fig. 1 Schematic diagram represents the reduction of $\mathrm{Au}^{3+}$ ion into $\mathrm{Au}^{0}$<smiles>O=C[C@H](O)[C@H](O)[C@H](O)[C@H](O)[C@H](O)[C@H](O)[C@H](O)CO</smiles>

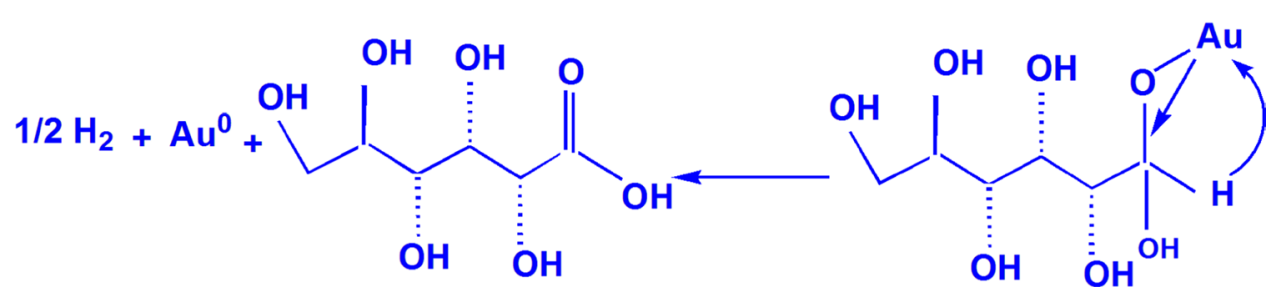


transferred to $\mathrm{Au}^{3+}$ and gets reduced into $\mathrm{Au}^{0}$. At last, the oxygen of $C=O$ group recovers the double bond and it is converted into gluconic acid [43].

\subsection{Justicia adhatoda extract as a stabilizing agent for AuNPs}

Silver ( $\mathrm{Ag}$ ) and gold (Au) nanoparticles are stabilized by hydroxyl $(-\mathrm{OH})$ groups present in the starch molecules [44]. The terminal D-glucose unit gets oxidized into gluconic acid in the presence of Au ions. The negative charge of the gluconic acid interacts with the surface positive charge of AuNPs by electrostatic interaction; this is the reason for bond formation between them. Thus, the capping agent is responsible for AuNPs stabilization.

\subsection{UV-Visible spectroscopy studies}

\subsubsection{Effect of contact time}

Formation of gold nanoparticle (AuNPs) was monitored with the help of UV-Vis spectroscopy. A gradual color change could be observed from pale yellow to ruby red color after the addition of gold chloride solution which indicates the formation of AuNPs. The Surface Plasmon resonance (SPR) band is due to the oscillation of free conduction electrons induced by an interacting electromagnetic field on the surface of gold nanoparticles. The SPR band of AuNPs were related to their size, shape and aggregation conditions $[45,46]$. The formation of AuNPs was confirmed by UV-Vis spectra (Fig. 2). The SPR peak is observed $542 \mathrm{~nm}$ which is gradually increased with the

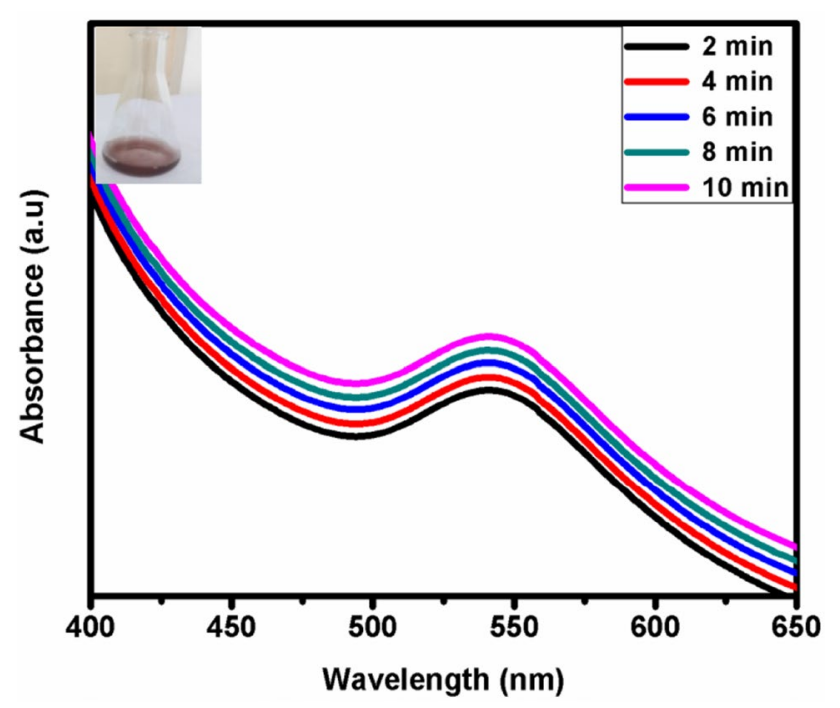

Fig. 2 UV-Vis spectra of AuNPs (Contact time for J. adhatoda leaf extract with $\mathrm{HAuCl}_{4}$ ) function of time (10-60 $\mathrm{min}$ ) and this is clearly exhibiting that the redox reaction has occurred between the aqueous extract and metal ions. Both of them were responsible for the formation of the stable AuNPs [47]. Early reports show that the temperature and $\mathrm{pH}$ parameters are vital factors which affecting the size and shape of the AuNPs [48-51]. The rate of formation of AuNPs increases with increase in the SPR band.

\subsubsection{Effect of quantity of leaf extract}

With an increasing ratio of leaf extract, subsequent color changes were noted from pink into reddish pink. In general, AuNPs is synthesized by direct deal with the quantity of aqueous extract, higher dosage of reducing agent will produce maximum yield of nanoparticle. The SPR peak of blue shift $(542,541$ and $540 \mathrm{~nm})$ for 1, 2 and 3 leaf extract respectively (Fig. 3). The formation of a blue shift indicates decreasing of the particle size [52-55].

\subsubsection{Effect of metal concentrations}

To examine the effect of metal salt concentration, the volume of leaf extract and $\mathrm{HAuCl}_{4}$ were kept constant (1:7), but the concentration of metal salt varied $(0.5,1.0$ and $1.5 \mathrm{mM}$ ). The rapid formation of dark pink color was noticed at high concentration of metal salt [56]. Figure 4 shows that the SPR peak intensity increases with increase in metal salt concentrations. The intensity of SPR peak and sharpness is increased at higher metal concentration which indicates increase of the size of nanoparticle $[56,58]$. By increasing the metal concentration, increases

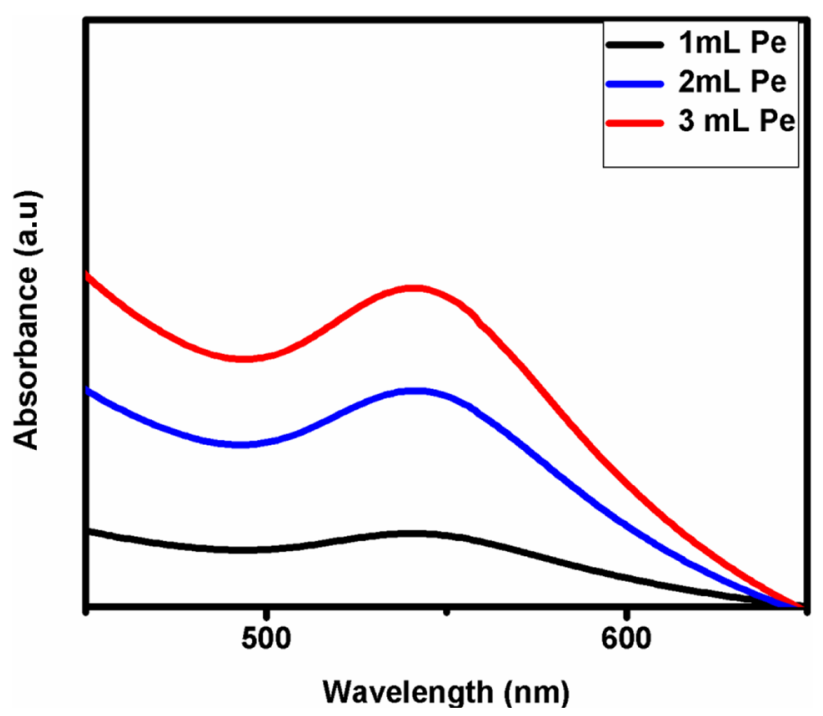

Fig. 3 UV-Vis spectra of AuNPs at different volume of J. adhatoda plant extract (PE) 


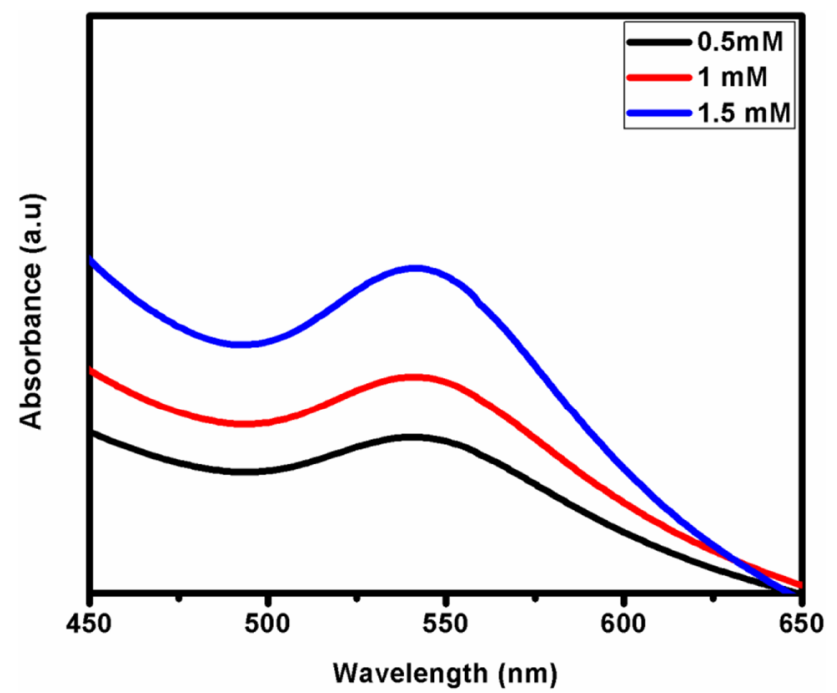

Fig. 4 UV-Vis spectra of AuNPs at various concentration of $\mathrm{HAuCl}_{4}$ $(0.5,1.0$ and $1.5 \mathrm{mM})$

the size of AuNPs $\left(a_{1}-a_{3}\right)$ was also found in SEM and TEM images (Figs. 4 and 5). Dubey et al. [57] have also reported that the rate of formation of AuNPs was found to be faster at highest metal salt concentration. Dwivedi et al. [59] reported that the less number and smaller size of nanoparticles was observed in lowest metal salt concentration.

\subsection{Morphological studies}

\subsubsection{SEM analysis}

The SEM images explain the morphological study of AuNPs $\left(a_{1}, a_{2}\right.$ and $\left.a_{3}\right)$ synthesized from $J$. adhatoda. The obtained AuNPs $\left(a_{1}, a_{2}\right.$ and $\left.a_{3}\right)$ were found to be spherical shape with and without aggregation. Shape of sample $a_{1}$ is uniform, but $\mathrm{a}_{2}$ and $\mathrm{a}_{3}$ samples are poly-dispersed in nature with slight aggregation are shown in Fig. 5a-c.

\subsubsection{TEM analysis}

The size and shape of the nanoparticles were further confirmed by TEM analysis. The TEM images in Fig. 6a-f prove the synthesized AuNPs are spherical in shape and their average sizes are 27.1, 33.3 and $46.8 \mathrm{~nm}$ for sample $\mathrm{a}_{1}, \mathrm{a}_{2}$ and $\mathrm{a}_{3}$ respectively. Some AuNPs are agglomerated in some places, thereby indicating possible deposition of nanoparticles after few days. Philip et al. [16, 60, 61] also discussed that the synthesized spherical shape of gold nanoparticles is due to the sharp SPR peak. TEM images also confirmed that the spherical shape and its sizes was increased with increase in the concentration of $\mathrm{HAuCl}_{4}$. Beside, analysis of the AuNPs by Energy Dispersive
Spectroscopy (EDAX) confirmed the occurrence of the signal feature of elemental gold (Fig. $6 \mathrm{~g}$ ). Maximum peaks are noticed for crystalline Au peaks and few peaks are observed for $\mathrm{Cu}$ comes from the copper grid. Thus, there are no foreign substances present in the sample. Figure $6 \mathrm{~h}$ shows Selected Area Electron Diffraction pattern (SAED) of the AuNPs and it is measured from one of the nanoparticles. The SAED images clearly exhibited the diffraction rings with interplanar spacing which denotes AuNPs are crystalline nature. SAED spots are related to the different crystallographic planes of FCC structure of elemental gold (Fig. 6h) The SAED spots are related to the different crystallographic plane families [111], [200] and [220] of pure face-centred cubic gold structure [62].

\subsection{Xrd}

The typical XRD pattern of fabricated AuNPs displayed, Bragg's reflection planes at (111), (200), (220) and (311) corresponds to $2 \theta$ values of the peaks at $38.3^{\circ}, 44.3^{\circ}, 64.5^{\circ}$ and $77.6^{\circ}$ respectively (Fig. 7) for $a_{1}-a_{3}$. All peaks of AuNPs (a1-a3), which are well matched with the standard data file (JCPDS file No. 99-101-3542). From this result, a number of prominent Bragg reflection peaks are based on Face Centered Cubic (FCC) crystalline nature of AuNPs. The reflection peaks are broader which indicates the smaller dimension of particles [63]. No other peaks are found in XRD pattern, which is confirmed the purity of AuNPs. Hence, the obtained pure crystalline nature of AuNPs was enclosed with biomolecules.

The peak $\left(38.3^{\circ}\right)$ corresponding plane is more intense than other planes. Thus, the plane is signifying one; this is due to the predominant progress of AuNPs along the direction of plane (111). The average nanocrystallite size is calculated by using Debye-Scherer equation and it is found to be 20.2, 40.1 and $40.3 \mathrm{~nm}$ for the corresponding samples $a_{1}, a_{2}$ and $a_{3}$ respectively, which slightly varied from the obtained particle sizes of TEM analysis of AuNPs (Fig. 6a-f). It shows slight changes of the spherical shape of particles that is needed the Debye-Scherer formula.

The average nanocrystalline material size has been calculated by Debye-Scherrer formula,

$\mathrm{D}=\mathrm{k} \lambda / \beta \cos \theta$,

where $D$ is particle diameter size, $k=1$ (constant), $\lambda$ wavelength of X-ray source $(0.1541 \mathrm{~nm}), \beta$ full width at half maximum (FWHM) and $\theta$ diffraction angle corresponding to the lattice plane (111).

\subsection{FTIR}

In order to inspect the AuNPs, they are capped with the biomolecules. FTIR analysis was carried out in order to 
Fig. 5 SEM images of AuNPs from $J$. adhatoda leaf extract a $\mathbf{a}_{1}, \mathbf{b} \mathrm{a}_{2}$ and $\mathbf{c} \mathrm{a}_{3}$
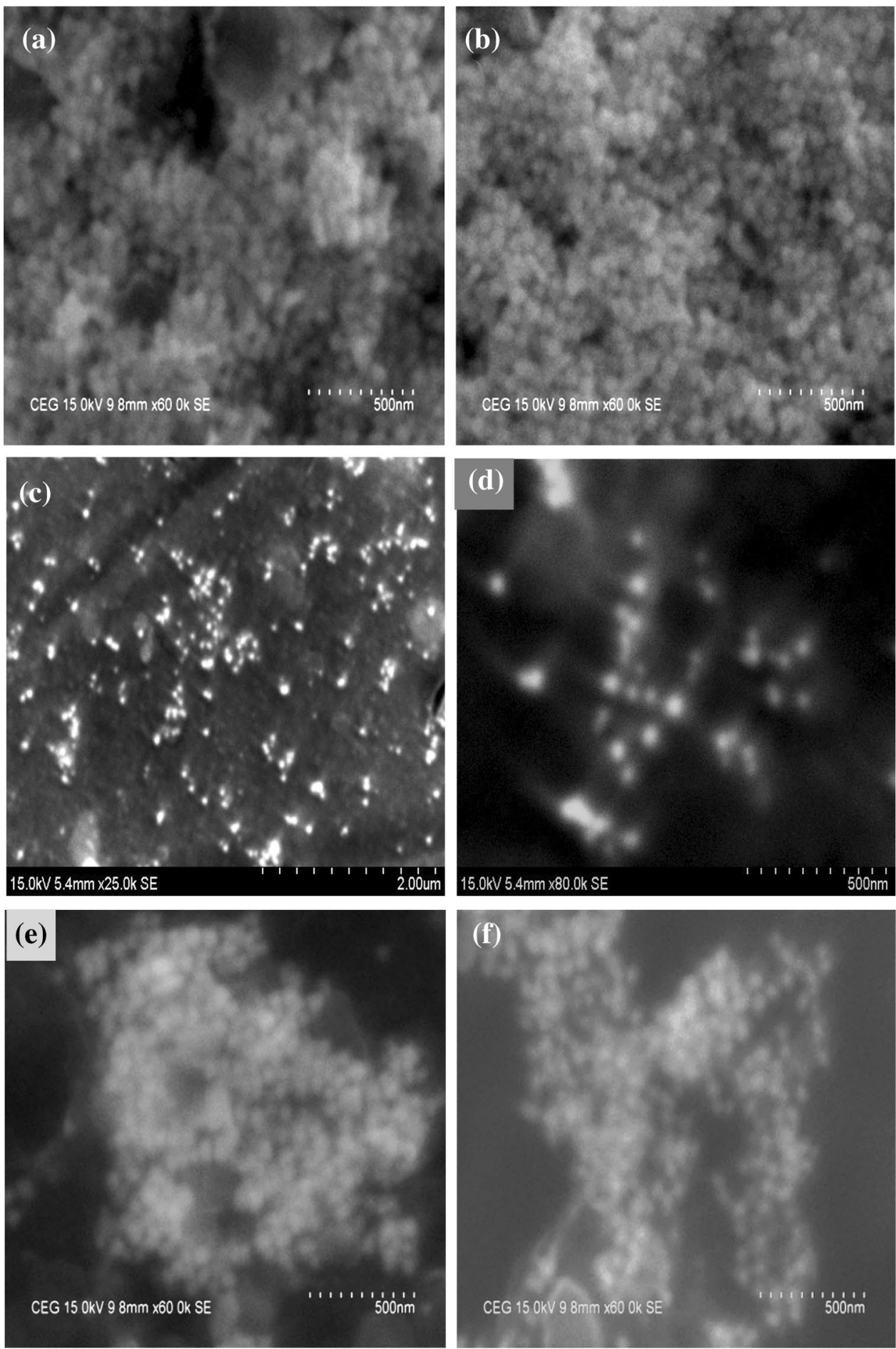

detect the potential biomolecules of J. adhatoda plant extract which are responsible for the reduction, capping and efficient stabilization of AuNPs. FTIR spectrum of aqueous leaf extract shows the stretching vibration peaks at 3404, 2938, 2846, 1636, 1408, 1050, 1257, 1082, 827 and $886 \mathrm{~cm}^{-1}$ (Fig. 8a). The synthesized AuNPs exhibit the peaks at $3402,2850,1636,1404,1081,661,600$ and
$522 \mathrm{~cm}^{-1}$ (Fig. 8b). The broad IR band at $3402 \mathrm{~cm}^{-1}$ is due to stretching vibrations of $\mathrm{O}-\mathrm{H}$ group [64]. A peak at $1634 \mathrm{~cm}^{-1}$ is attributed to $\mathrm{C}-\mathrm{O}$ stretching vibrations in the amide I shifted to $1636 \mathrm{~cm}^{-1}$ the protein molecules are possible to bind with AuNPs via carboxylate groups $\left(-\mathrm{COO}^{-}\right)[25,64-66]$. The peak at $1408 \mathrm{~cm}^{-1}$ is due to $\mathrm{COO}^{-}$symmetric stretching of chloroplasts shifted to 
Fig. 6 TEM images of AuNPs synthesized from $J$. adhatoda leaf extract $\mathbf{a}, \mathbf{b} \mathrm{a}_{1}, \mathbf{c}, \mathbf{d} \mathrm{a}_{2}, \mathbf{e}$, f $\mathrm{a}_{3}, \mathbf{g}$ EDX and $\mathbf{h}$ SAED
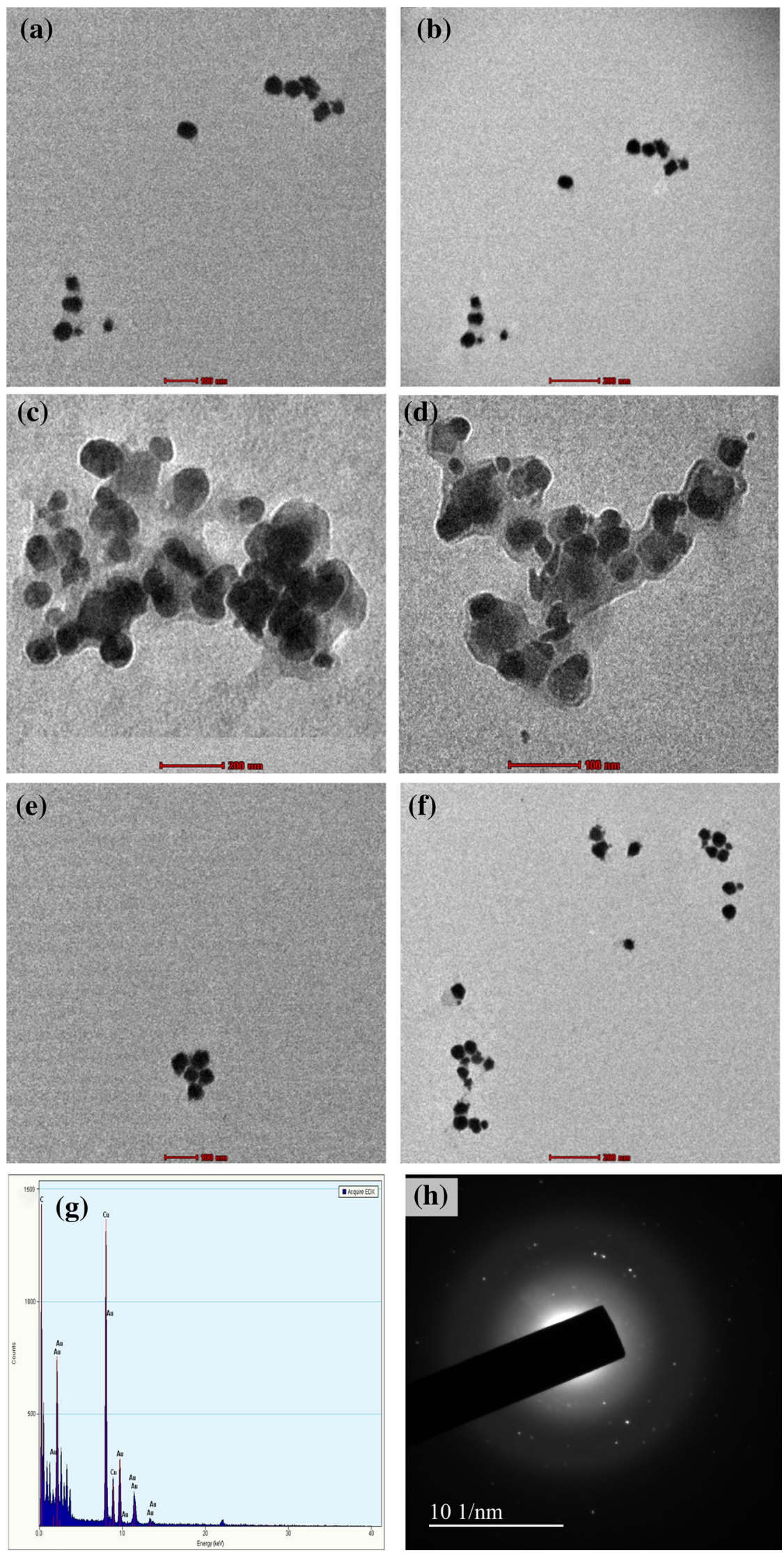

SN Applied Sciences A SPRINGER NATURE journa 


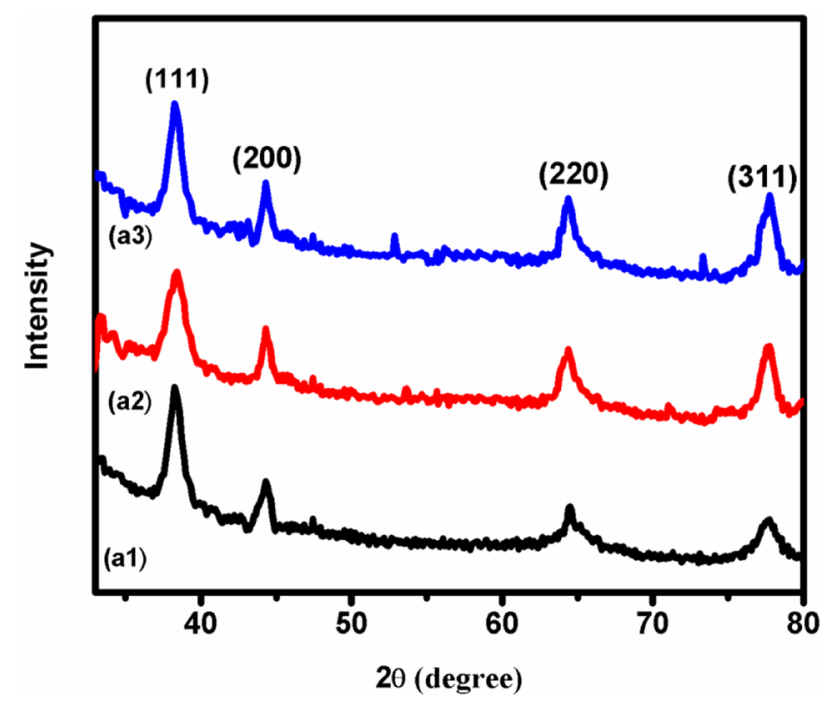

Fig. 7 XRD pattern of AuNPs for $\mathbf{a} \mathbf{a}_{1}, \mathbf{b} \mathrm{a}_{2}$ and $\mathbf{c} \mathrm{a}_{3}$
$\mathrm{O}-\mathrm{H}\left(3402 \mathrm{~cm}^{-1}\right)$ and $(\mathrm{NH}) \mathrm{C}=\mathrm{O}$ groups $\left(1636 \mathrm{~cm}^{-1}\right) \mathrm{can}$ bind with AuNPs $[25,64]$. Based on the above mentioned facts, it is confirmed that the reducing sugar (D-glucoside) and protein molecules are responsible for reduction of $\mathrm{Au}^{3+}$ and capping agent of AuNPs.

\subsection{Catalytic activity studies}

\subsubsection{Catalytic activity of synthesized gold nanoparticles in Congo red}

The present study demonstrates the size-dependent, catalytic activity of AuNPs against Congo red dye in the presence of the $\mathrm{NaBH}_{4}$. The absorption band of Congo red is about 486-498 $\mathrm{nm}$ [39]. The absorption peak of Congo red was observed at $496 \mathrm{~nm}$ and the peak intensity decreased during the reduction. This is due to the degradation of Congo red by AuNPs in the presence of $\mathrm{NaBH}_{4}$. Schematic diagram exhibits the possible structure of Congo
Fig. 8 FTIR spectra of a J. adhatoda plant and $\mathbf{b}$ AuNPs
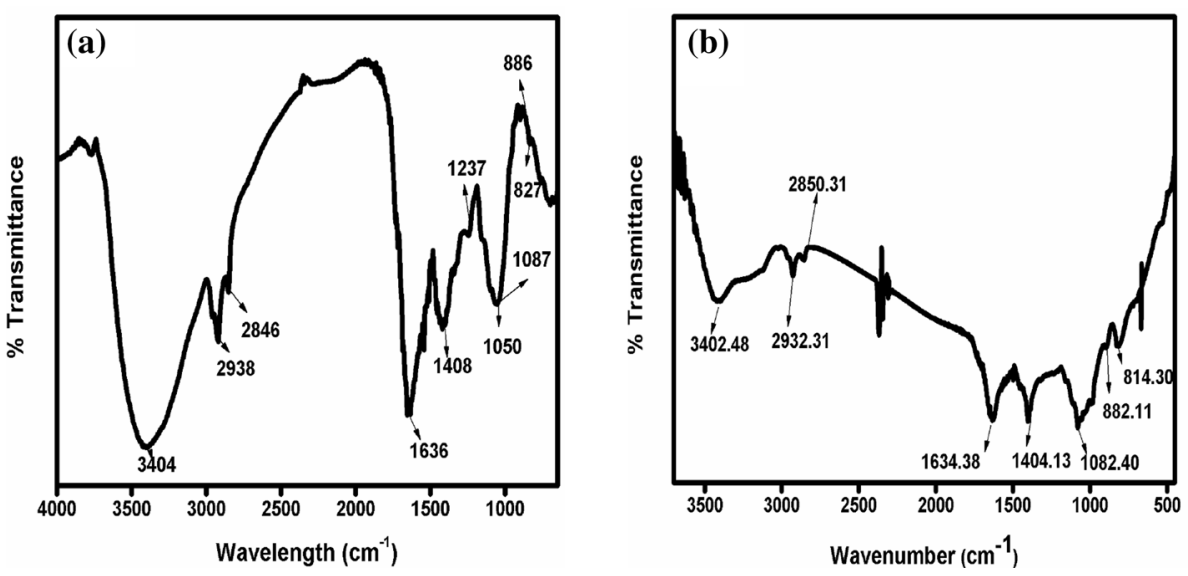

Fig. 9 Schematic diagram for Congo red degraded into protonated Congo red in the presence of synthesized AuNPs

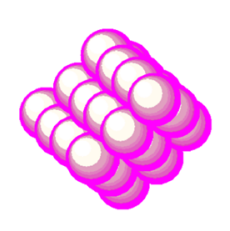

AuNPs<smiles>Nc1c(N=Nc2ccc(-c3ccc(N=Nc4cc(S(=O)(=O)[O-])c5ccccc5c4N)cc3)cc2)cc([AsH3])c2ccccc12</smiles>

Congored

Color less Congored

$1404 \mathrm{~cm}^{-1}$ [67]. A minor peak at about $661 \mathrm{~cm}^{-1}$ is due to $\mathrm{C}-\mathrm{Cl}$ or $\mathrm{C}-\mathrm{Br}$ stretch of alkyl halides [68]. In FTIR, such kind of shifting vibrational spectra has been ascribed that the red dye degradation (Fig. 9). Figure 10a, b illustrates the catalytic degradation of Congo red by using two different 
Fig. 10 UV-Vis spectra for degradation of Congo red dye without using AuNPs in the presence of $\mathbf{a} 0.1 \mathrm{M}$ and $\mathbf{b}$ $0.2 \mathrm{M} \mathrm{NaBH}_{4}$
Fig. 11 UV-Vis spectral analysis of Congo red using $\mathrm{NaBH}_{4}$ $(0.1 \mathrm{M})$ with addition of $500 \mu \mathrm{L}$ of AuNPs $\mathbf{a} \mathbf{a}_{1}, \mathbf{b} \mathrm{a}_{2}, \mathbf{c} \mathrm{a}_{3}$ and $\mathbf{d}$ linear plot of kinetic data for $a_{1}-a_{3}$ samples
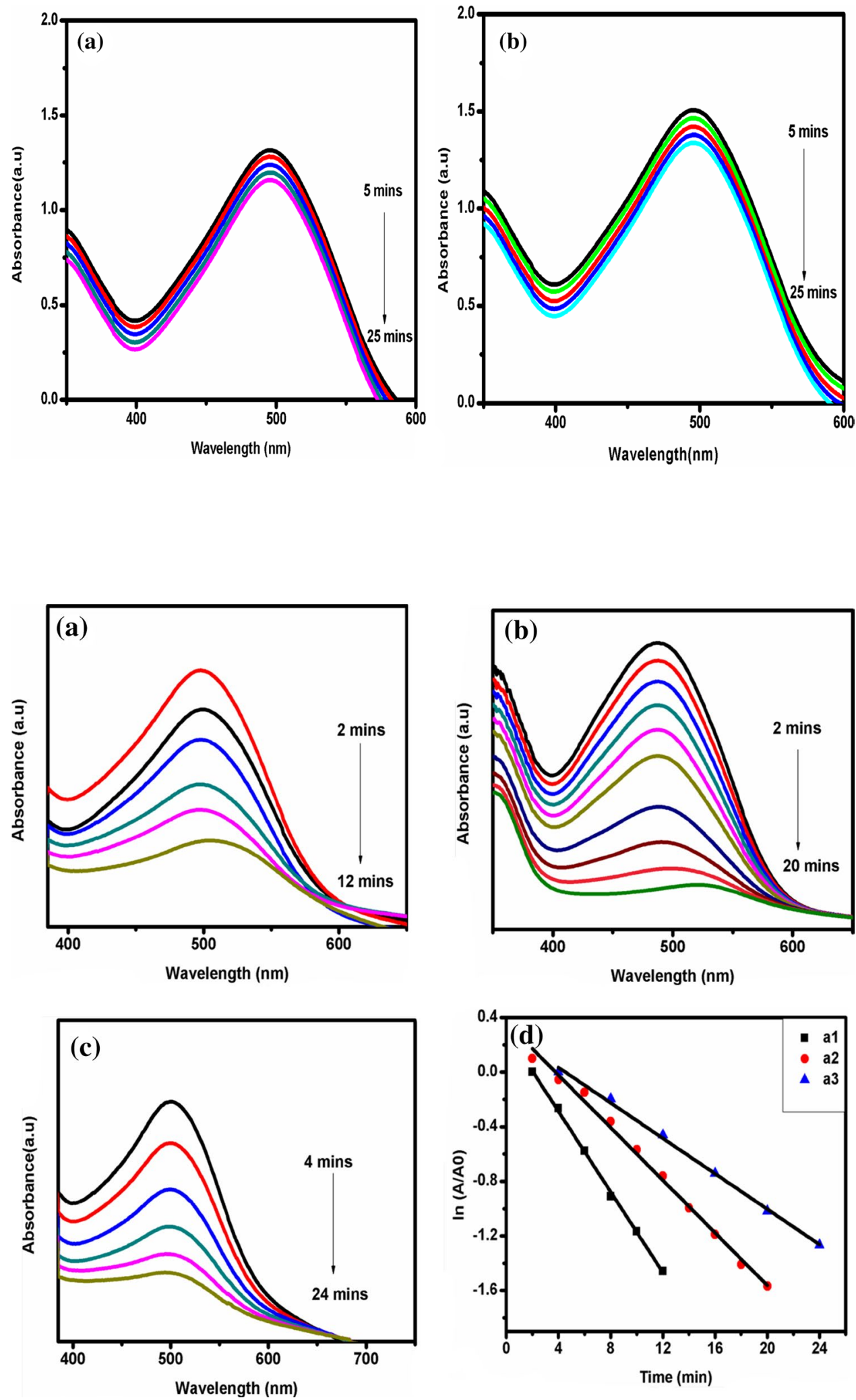

concentrations of $\mathrm{NaBH}_{4}(0.1$ and $0.2 \mathrm{M})$ in the absence of AuNPs independently. The degradation was slow in both cases when increasing the concentration of $\mathrm{NaBH}_{4}(0.1$ and $0.2 \mathrm{M}$ ) meanwhile after addition of AuNPs, the degradation was faster. Narayanan et al. [69-71] discussed that $\mathrm{NaBH}_{4}$ is a weak reducing agent which was used in a lot of industrial processes as well as in wastewater treatment. The reduction process found to speed up by adding samples $a_{1}-a_{3}$. 
Figure $11 \mathrm{a}-\mathrm{c}$ shows the samples $\mathrm{a}_{1}, \mathrm{a}_{2}$ and $\mathrm{a}_{3}$ degraded the dye within 12,20 and 24 min respectively. The catalytic reduction of $a_{1}$ was faster than other samples $a_{2}$ and $a_{3}$. From this observation, the degradation time decreased while using smaller size of the nanoparticles $\left(a_{1}\right)$. The sample $a_{1}$ increases the catalytic property, their larger surface area will enhance the catalytic activity $[72,73]$. A good linear correlation was observed between $\ln \left(A / A_{0}\right)$ versus time (Fig. 11d). The overall reduction reaction was hypothetical pseudo first order reaction. The rate of reaction also increased with decrease in nanoparticles sizes [5]. The obtained rate constant values from the plot $\ln A / A_{0}$ versus time for all five samples are shown in Table 1. The electron transfer from donor $\left(\mathrm{BH}^{-}\right)$to acceptor (Congo red dye) through the surface of AuNPs [39]. The plant extract having different functional groups are enhancing the catalytic

Table 1 Rate constants of Congo red dye reduction

\begin{tabular}{lllll}
\hline Sample code & $\begin{array}{l}\text { Conc of } \\
\mathrm{NaBH}_{4}(\mathrm{M})\end{array}$ & $\begin{array}{l}\text { Volume of } \\
\text { AuNPs }(\mu \mathrm{L})\end{array}$ & $\begin{array}{l}\text { Rate } \\
\text { constants } \\
\left(\mathrm{min}^{-1}\right)\end{array}$ & $R^{2}$ value \\
\hline $\mathrm{a}_{1}$ & 0.1 & 500 & 0.1475 & 0.99854 \\
$\mathrm{a}_{2}$ & 0.1 & 500 & 0.09633 & 0.99407 \\
$\mathrm{a}_{3}$ & 0.1 & 500 & 0.06486 & 0.99707 \\
\hline
\end{tabular}

activity of AuNPs [74]. This study exhibits an overwhelming performance as a catalyst, depending on its size.

\subsubsection{Catalytic activity of synthesized AuNPs in Methylene blue}

The catalytic activity of AuNPs was demonstrated by the degradation of Methylene blue along with $\mathrm{NaBH}_{4}$. The absorbance peak of Methylene blue was observed at $664 \mathrm{~nm}$ and with a shoulder peak at $614 \mathrm{~nm}$ is due to $n-\pi^{*}$ transition. The decreasing tendency of maximum absorption denotes the reduction of Methylene blue [72]. A possible mechanism for Methylene blue dye degradation has shown in schematic diagram in Fig. 12. Figure 13a and $b$ demonstrate the UV-Vis absorption spectra of the reduction of Methylene blue by using two various concentrations of reducing agent $(0.1$ and $0.2 \mathrm{M})$ without adding AuNPs. The degradation was slow in 30 min period of time even increasing the concentrations of $\mathrm{NaBH}_{4}[39$, 40]. When adding AuNPs $\left(a_{1}-a_{3}\right)$ to the reaction mixture the reduction was fast respectively. Hence, the reduction reaction was found to be faster in sample $a_{1}$ rather than $a_{2}$ and $a_{3}$ samples. The degradation of dye when using $a_{1}, a_{2}$ and $a_{3}$ samples within 5,8 and 15 min respectively (Fig. 14a-c). Based on the above observation, that the degradation time was decreasing with decrease in the
Fig. 12 Schematic diagram for Methylene blue degraded into Leuko Methylene blue in the presence of synthesized AuNPs

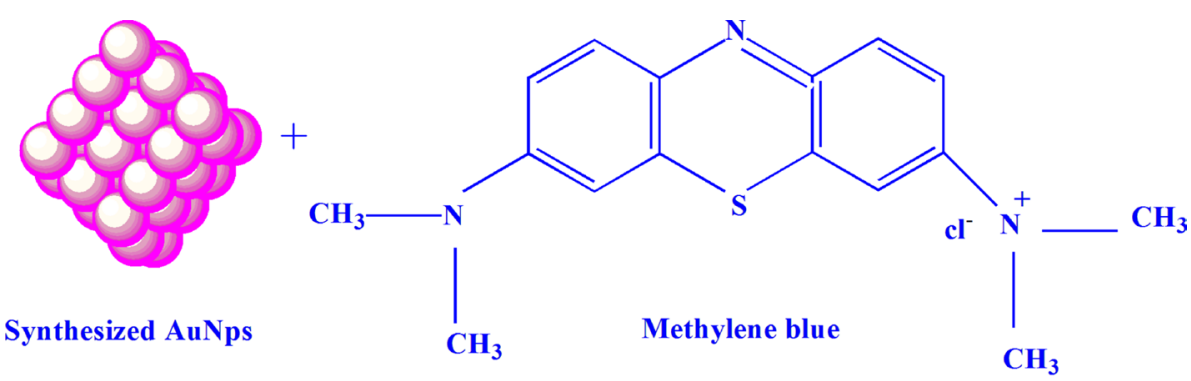<smiles>CN(C)c1ccc2c(c1)Sc1cc(N(C)C)ccc1N2</smiles>

Leuko methylene blue 
Fig. 13 UV-Vis analysis for the degradation of Methylene blue without addition of AuNPs using different concentration of $\mathrm{NaBH}_{4}$ a $0.1 \mathrm{M}$ and $\mathbf{b} 0.2 \mathrm{M}$

Fig. 14 UV-Vis spectra for Methylene blue using $\mathrm{NaBH}_{4}$ with addition of $500 \mu \mathrm{L}$ of AuNPs $\mathbf{a} \mathrm{a}_{1}, \mathbf{b} \mathrm{a}_{2}, \mathbf{c} \mathrm{a}_{3}$ sample and $\mathbf{d}$ linear plot of kinetic data for $\mathrm{a}_{1}-\mathrm{a}_{3}$ samples
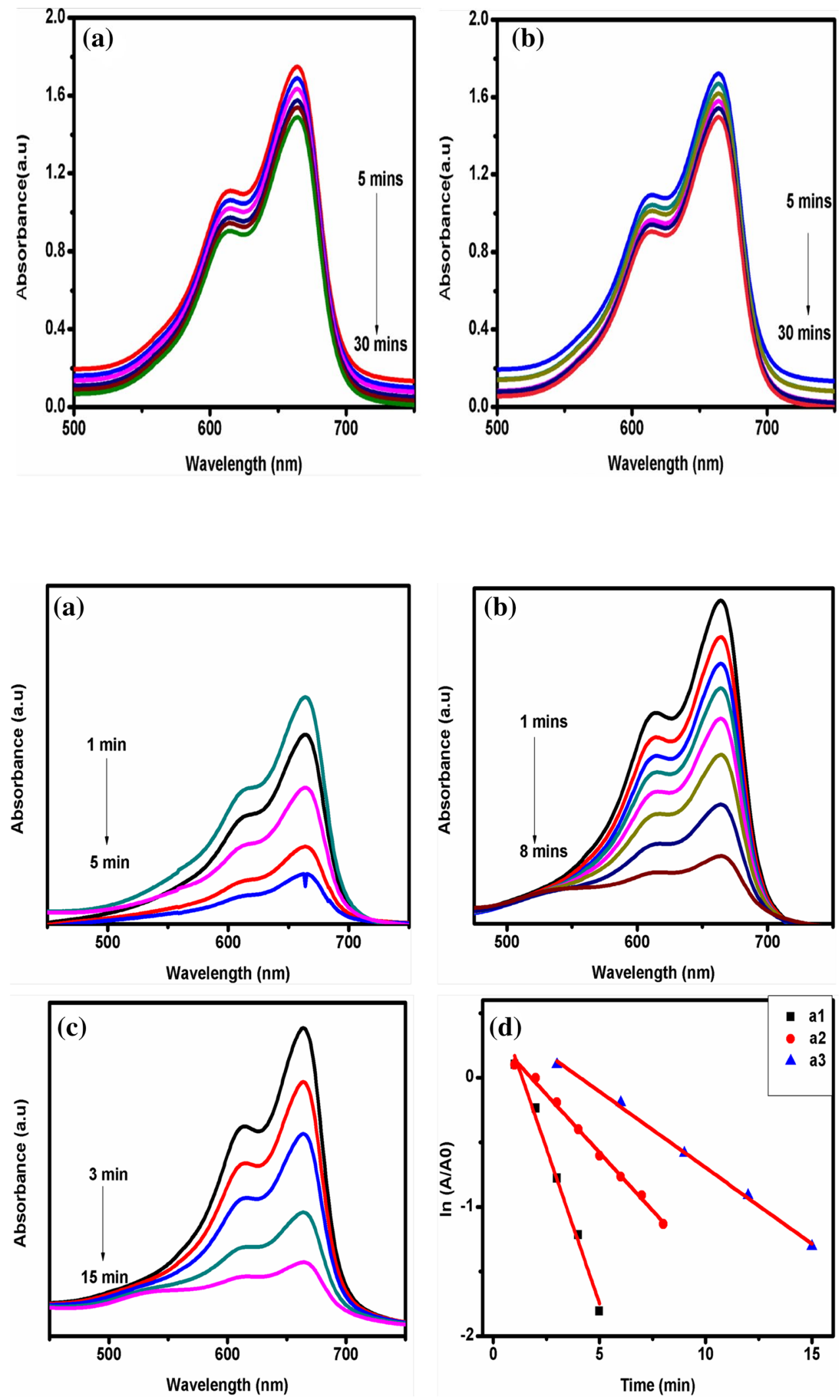
Table 2 Rate constants of Methylene blue dye reduction

\begin{tabular}{lllll}
\hline Sample code & $\begin{array}{l}\text { Conc of } \\
\mathrm{NaBH}_{4}(\mathrm{M})\end{array}$ & $\begin{array}{l}\text { Volume of } \\
\text { AuNPs }(\mu \mathrm{L})\end{array}$ & $\begin{array}{l}\text { Rate } \\
\text { constants } \\
\left(\mathrm{min}^{-1}\right)\end{array}$ & $R^{2}$ value \\
\hline $\mathrm{a}_{1}$ & 0.1 & 500 & 0.47948 & 0.99055 \\
$\mathrm{a}_{2}$ & 0.1 & 500 & 0.17961 & 0.99546 \\
$\mathrm{a}_{3}$ & 0.1 & 500 & 0.11769 & 0.99716 \\
\hline
\end{tabular}

size of AuNPs $\left(a_{1}-27.1 \mathrm{~nm}\right)[39,40]$. The smaller size of AuNPs will increase the catalytic activity, due to their larger surface area [69]. The rate of reaction was also increased with decrease in nanoparticles sizes [5]. The rate of catalytic degradation increased with increase in the dosage of catalyst [75]. A good linear correlation plot was observed between $\ln A / A_{0}$ versus time graph (Fig. 14d). From the plot of In $A / A_{0}$ versus time, the rate constant values for all the five samples are shown in Table 2. AuNPs are assisting the electron transmission from donor $\left(\mathrm{BH}^{-}\right)$to acceptor (Methylene blue) in the redox reaction which is termed as an electron relay effect [71]. The percentage of dye degradation can be calculated using the following equation.

$\%$ of dye degradation $=\frac{A_{0}-A}{A_{0}} \times 100$

$\mathrm{A}_{0}$ initial absorbance, $\mathrm{A}$ absorbance at time.

Therefore, the catalytic reduction reactions (Congo red and Methylene blue), was carried out as-synthesized AuNPs acted as a potential catalyst. Table 3 represents a comparative literature survey of dye degradation, against Congo red and Methylene blue by different nanoparticles.

\section{Conclusion}

We disclosed an ecofriendly approach for synthesis of stable AuNPs using J. adhatoda leaf extract. The concentration of metal was essential in synthesis of various sizes of AuNPs. The spherically crystalline nature of AuNPs was encircled with the D-gulcoside and protein molecules. When there is increase in concentration of reducing agent, the degradation did not show better results, meanwhile after the addition of AuNPs, the degradation was good. Then, the obtained AuNPs was efficient in catalytic dye degradation. This study reveals that the smaller size of AuNPs enhances the catalytic activity due to their large surface area. From the above result, we concluded the most excellent degradation was found in Methylene blue than Congo red. Finally, green synthesized AuNPs are effective nano-catalyst and could be made potentially exciting for large scale synthesis of AuNPs.

Acknowledgements We acknowledge the support extended by University of Madras, IIT, Chennai and TNAU, Coimbatore, India for providing research facilities.

\section{Compliance with ethical standards}

Conflict of interest The authors declare that they have no competing interests.

\section{References}

1. Philip D (2010) Honey mediated green synthesis of silver nanoparticles. Spectrochim Acta A 77:807-810

2. Rai M, Gade AY (2011) Biogenic nanoparticles: an introduction to what they are how they are synthesized and their applications. Springer, Berlin, pp 12-26

3. Raveendran P, Fu J, Wallen S-L (2003) Completely “Green" synthesis of metal nanoparticles. J Am Chem Soc 125:13940-13941

4. Park Y, Hong Y-N, Weyers A, Kim Y-S, Linhardt R-J (2011) Polysaccharides andphytochemicals: a natural reservoir for the green synthesis of gold and silvernanoparticles. IET Nanobiotechnol 5(3):69-78

5. Suvith V-S, Philip D (2014) Catalytic degradation of Methylene blue using biosynthesized gold and silver nanoparticles. Spectrochimi Acta A 118:526-532

6. Daniel M-C, Astruc D (2004) Gold nanoparticles: assembly supra molecular chemistry quantum-size related properties and
Table 3 Review of various nanoparticles utilized for degradation of Methylene blue (MB) and Congo red dye (CR)

\begin{tabular}{lllllll}
\hline S. No & Source & Nano particles & Dye & Time (min) & $\begin{array}{l}\text { Rate } \\
\text { constant } \\
\left(\mathrm{min}^{-1}\right)\end{array}$ & Author \\
& & & & & \\
\hline 1 & Saraca indica & AgNps & MB & 12 & 0.4416 & {$[73]$} \\
2 & Brassica rapa & AuNPs & MB & 18 & 0.372 & {$[69]$} \\
3 & Salmaliamala barica gum & AuNPs & MB & 9 & 0.241 & {$[58]$} \\
& & & CR & 10 & 0.236 & \\
4 & Amaranthus gangeticus & AgNps & CR & 15 & - & {$[76]$} \\
5 & Mushroom & AuNPs & MB & 23 & 0.0529 & {$[77]$} \\
6 & Bacillusmarisflavi & AuNPs & CR & 20 & 0.2192 & {$[39]$} \\
7 & Justicia adhatoda & AuNPs & CR & 12 & 0.1475 & Present study \\
& & & MB & 5 & 0.47948 & \\
\hline
\end{tabular}


applications towards biology catalysis and nanotechnology. Chem Res 104:293-346

7. John Paul J, Aseniero Einstine, Piso MO, Banda MHT, Tabelin CB (2019) Potentialutilization of artisanal gold-mine tailings as geopolymeric source material: preliminary investigation. SN Appl Sci 1:35

8. Alaqad K, Saleh T-A (2016) Gold and silver nanoparticles: synthesis methods, characterization routes and applications towards drugs. J Environ Anal Toxicol 6(4):1000384

9. Jafarizad K, Safaee S, Gharibian Y, Omidi D, Ekinci D (2015) Biosynthesis and in vitro study of gold nanoparticles using mentha and pelargonium extracts. Proc Mat Sci 11:224-230

10. Grumezescu A-M, Sengani M, Rajeshwari V-D (2017) Recent trends and methodologies in gold nanoparticle synthesis- $A$ prospective review on drug delivery aspect. Open Nano 2:37-46

11. Iqbal M, Usanasea G, Oulmib K, Aberkaneb F, Bendaikhab T, Fessia H, Zinec N, Agustia G, El-S Errachidc, Elaissari A (2016) Preparation of gold nanoparticles and determination of their particles size via different methods. Mat Res Bul 79:97-104

12. Han L-S, Kyu J-H, Cheol K-T, Hee K-C, Hwan S-C, Tae-Sik Y, Ra H-A, Seong J-H, Hun K-D (2018) Facile method for the synthesis of gold nanoparticles using an ion coater. Appl Sur Sci 434:1001-1006

13. Song J-Y, Jang H-K, Kim B-S (2009) Biological synthesis of gold nanoparticles using Magnolia kobusand Diopyros kaki leaf extracts. Proc Biochem 44:133-1138

14. Majumdar R, Bag B-J, Maity N (2013) Acacianilotica (Babool) leaf extract mediated sizecontrolled rapid synthesis of gold nanoparticles and study of its catalytic activity. Int Nano Lett 3:53

15. Sett A, Gadewar M, Sharma P, Deka M, Bora U (2016) Green synthesis of gold nanoparticles using aqueous extract of Dilleniaindica. Adv Nat Sci Nanosci Nanotech 7:025005

16. Philip D (2009) Honey mediated green synthesis of gold nanoparticles. Spectrochimica Acta A 73:650-653

17. Smitha S-L, Philip D, Gopchandran K-G (2009) Green synthesis of gold nanoparticles using Cinnamomumzey lanicum leaf broth. Spectrochimica Acta Part A 74:7

18. Pathak R-P (1970) Shri Ramdayal Joshi Memorial Ayurvedic Research Institute 1:121

19. Singh T-P, Singh O-M, Singh H-B (2011) Adhatodavasica Nees: phytochemical and pharmacological profile. Nat Prod J 1:29-39

20. Dhankhar S, Kaur R, Ruhil S, Balhara M, Dhankhar S, Chhillar A-K (2011) A review on Justiciaadhatoda: a potential source of natural medicine. Afri J Plant Sci 5(11):620-627

21. McMullan G, Meehan C, Conneely A, Kirby N, Robinson T, Nigam P, Banat I-M, Marchant R, Smyth WF (2001) Microbial decolorization and degradation of textile dyes. Appl Microbiol Biotechnol 56:81-87

22. Pearce C-I, Lloyd J-R, Guthrie J-T (2003) The removal of colour from textile wastewater using whole bacterial cells: a review. Dyes Pigments 58:179-196

23. Lee J-W, Choi S-P, Thiruvenkatachari R, Shim W-G, Moon H (2006) Evaluation of the performance of adsorption and coagulation processes for the maximum removal of reactive dyes. Dyes Pigments 69(3):196-203

24. Rafi F, Franklin W, Cerniglia CE (1990) Azoreductase activity of an aerobic bacteria isolated from human interstinalmicroflora. Appl Environ Microbiol 56:2146-2151

25. Sodeinde O, Eboreime U (2013) Adsorption of textile wastes containing Methylene blue and congo red using activated carbon produced from coconut shell. Int J Computat Eng Manag 16(5):2230-7893

26. Yang G, Wu L, Xian Q, Shen F, Wu J, Zhang Y-Z (2016) Removal of congo red and Methylene blue from aqueous solutions by vermicompost-derived. Biochars PLoS ONE 11(5):0154562
27. Gillman P-K (2006) Methylene blue implicated in potentially fatal serotonin toxicity. Anaesthesia 61:1013-1014

28. Oliveira L-S, Franca A-S, Rocha S-D, Alves M-T (2008) Evaluation of untreated coffee husk as potential biosorbent for treatment of dye contaminated water. J Harz Mat 155(3):507-512

29. Raymundo A-S, Zanarotto R, Belisário M, Pereira M-G, Ribeiro $J-N$, Ribeiro A (2010) Evaluation of sugar-cane bagasseasbioaddsorbent in the textile waste water treatment contaminated with carcinogenic congoreddye. Braz Arch Biotechnol 53(4):931-938

30. Banat I-M, Nigam P, Singh D, Marchant R (1996) Microbial decolorization of textile dye containing effluents. Bioresour Technol 58:217-227

31. HanR Zhang J, Zou W, Shi J, Liu H (2005) Equilibriumbiosorption isotherm for lead ion on chaff. J Harz Mat 125(1-3):266-271

32. Ho Y-S, Chiu W-T, Wang C-C (2005) Regression analysis for the sorption isotherm of basic dyes on sugar-cane dust. Bioresour Technol 96(11):1285-1291

33. Kumar K-V (2006) Linear and non-linear regression for the sorption kinetics of Methylene blue onto activated carbon. J Harz Mater 137(3):1538-1544

34. Ho Y-S (2006) Second-order kinetic model for the sorption of cadmium onto tree feron: a comparision linear and non-linear methods. Water Res 40(1):119-125

35. Gupta V-K, Ali I, Suhas X, Mohan D-J (2003) Equilibrium uptake and sorption dynamics for the removal of a basic dye (basic red) usinglow-cost adsorbents. Coll Interf Sci 265:257

36. Santhi T, Manonmani S, Smitha T (2010) Removal of methyl red from aqueous solution by activated carbon prepared from the annonasqumosa seed by adsorption. Chem Eng Res Bull 14:11-18

37. Malana M-A, ljaz S, Ashiq N (2010) Removal of various dyes from media onto polymeric gels by adsorption process: their kinetics and thermodynamics. Desalination 263:249-257

38. Wang L-G, Yan G-B (2011) Adsorptive removal of direct yellow 161 dye from aqueous solution using bamboo charcoal activated with different chemicals. Desalination 274:81-90

39. Nadaf N-Y, Kanase S-S (2016) Biosynthesis of gold nanoparticles by Bacillus marisflavi and its potential in catalytic dye degradation. Arab J Chem 09:20

40. Chairam N-Y, Konkamdee W-S, Parakhun R (2017) Starch-supported gold nanoparticles and their use in 4-nitrophenol reduction. J Saudi Chem Soc 21:656-663

41. Liu X, Yu L, Xie F, Li M, Chen L, Li X (2010) Kinetics and mechanism of thermal decomposition of corn starches with different amylose/amylopectin ratios. Starch/Stärke 62:139-146

42. Benet $W-E$, Lewis G-S, Yang L-Z, Hughes D (2011) The mechanism of the reaction of the Tollens reagent. J Chem Res 35:675-677

43. Liu J, Qin G, Raveendran P, Ikushima Y (2006) Facile "green" synthesis, characterization and catalytic function of DGlucose- stabilized Au nanocrystals. Chem Eur J 12:2131-2138

44. Hussain S-T, Iqbal M, Mazhar M (2009) Size control synthesis of starch capped-gold nanoparticles. J Nanopart Res 11:1383-1391

45. Xia Y, Sun Y (2003) Gold and silver nanoparticles: a class of chromophores with colors tunable in the range from 400 to $750 \mathrm{~nm}$. Analyst 128:686-691

46. Slocik J-M, Zabinski J-S, Phillips D-M, Naik R-R (2008) Colorimetric response of peptide functionalized gold nanoparticles to metal ions. Small 4:548-551

47. Shankar S-S, Rai A, Ankamwar B, Singh A, Ahmad A, Sastry M (2004) Biological synthesis of triangular gold nanoprisms. Nat Mat 3:482-488

48. Annadhasan $M$, Muthukumarasamyvel T, Muthukumarasamyvel T, Babu V-R-S, Rajenindiran N (2014) Green synthesized silver and gold nanoparticles for colorimetic detection of $\mathrm{Hg}^{2+} \mathrm{Pb}^{2+}$ and $\mathrm{Mn}^{2+}$ aqueous medium. ACS Sustain Chem Eng 2:887-896 
49. Vigderman L, Zubarev E-R (2012) High-yield synthesis of gold nanorod with longitudinal SPR peak greater than $1200 \mathrm{~nm}$ using hydroquinone as a reducing agent. Chem Mat 25:1450-1457

50. Iglesias S, Pastoriza-Santos I, Perez-Juste J, Rodriguez-Gonzalez B, Garciade Abajo F-J, Liz-Marzan L-M (2006) Synthesis and optical properties of gold nanodecahedra with size contol. Adv Mater 18:2529-2534

51. Sau T-K, Murphy C-J (2004) Seeded high yield synthesis of short Au nanorods in aqueous solution. J Am Chem Soc 126:8648-8649

52. Zou L, Qi W, Su R, Huang R, He Z, Wang M (2013) Green synthesis of gold nanoparticles-nanocluster composite and nanostructures as linking and reducing agent. ACS Sustain Chem Eng 1:1398-1404

53. Noruzi M, Zare D, Khoshnevisan K, Davoodi D (2011) Rapid green synthesis of gold nanoparticles using Rosa hybrida petal extract at room temperature. Spectrochim Acta A 79:1461-1465

54. Hu M, Chen J, Li Z-Y, Au L, Hartland G-V, Li X, Marquez M, Xia Y (2006) Gold nanostructures: engineering their plasmonic properties for biomedical applications. Chem Soc Rev 35:1084-1094

55. Tagad CK, Dugasani S-R, Aiyer R, Park S, Kulkarni A, Sabharwal S (2013) Green synthesis of silver nanoparticles and their application for the development of optical fiber based hydrogen peroxide sensor. Sensors Actuators B 183:144-149

56. Shivshankar S, Ahmad A, Pasricha R, Sastry M (2003) Bioreduction of chloroaurate ions by geranium leaves and its endophytic fungus yields gold nanoparticles of different shapes. J Mat Chem 3:1822-1826

57. Dubey S-P, Lahtinen M, Sillanpää M (2010) Green synthesis and characterizations of silver and gold nanoparticles using leaf extract of Rosa rugosa. Colloids Surf A Physicochem Eng Asp 364:34-41

58. Ganapuram B-R, Alle M, Dadigala R, Dasari A, Maragoni V, Guttena V (2015) Catalytic reduction of Methylene blue and Congo red dyes using green synthesized gold nanoparticles capped by salmaliamala baricagum. Int Nano Lett 5:215-222

59. Dwivedi A-D, Gopal K (2010) Biosynthesis of silver and gold nanoparticles using Chenopodium album leaf extract. Colloids Surf A: Physicochem Eng Asp 369:27-33

60. Ibrahim HMM (2015) Green synthesis and characterization of silver nanoparticles using banana peel extract and their antimicrobial activity against representative microorganisms. J Radiat Res Appl Sci 8:265-275

61. Verma A, Mehata M-S (2016) Controllable synthesis of silver nanoparticles using neem leaves and their antimicrobial activity. J Radiat Res Appl Sci 9:109-115

62. Bhattacharyya R, Roy S, Prakash O, Singh A-P, Bhattacharya T-K, Maiti P, Bhattacharyya S, Das S (2019) $0.5 \mathrm{Zn0} 0.5 \mathrm{Fe}_{2} \mathrm{O}_{4}$ polyurethane thin nanocomposite coating as broadband microwave absorber. SN Appl Sci 1:38

63. Lokina S, Stephen A, Kaviyarasan V, Arulvasu C, Narayanan V (2014) Cytotoxicity and antimicrobial activities of green synthesized silver nanoparticles. Eur J MedChem 76:256-263
64. Adavallan K, Krishnakumar N (2014) Mulberry leaf extract mediated synthesis of gold nanoparticles and its anti-bacterial activity against human pathogens. Adv Nat Sci Nanosci Nanotechnol 5:025018

65. Gurunathan S, Han J, Park J-H, Kim J-H (2014) A green chemistry approach for synthesizing biocompatible gold nanoparticles. Nanoscale Res Lett 9:248

66. Gole C, Dash V, Ramakrishnan S-R, Sainkar A-B, Mandale M, Sastry R-M (2001) Pepsin-gold colloid conjugates: preparation characterization and enzymatic activity. Langmuir 17:1674-1679

67. Zhang Y-X, Zheng J, Gao G, Kong Y-F, Zhi X, Wang K, Zhang X-Q, Cui D-X (2011) Biosynthesis of gold nanoparticles using chloroplasts. Int J Nanomed 6:2899-2906

68. Nagaonkar D, Rai M (2015) Sequentially reduced biogenic silver-gold nanoparticles with enhanced antimicrobial potential over silver and gold monometallic nanoparticles. Adv Mat Lett 6(4):334-341

69. Narayanan K-B, Park H-H (2015) Homogeneous catalytic activity of gold nanoparticles synthesized using turnip (Brassica rapa L.) leaf extract in the reductive degradation of cationic azodye. Korean J Chem Eng 32(7):1273-1277

70. Rajan A, Meenakumari M, Philip D (2014) Shape tailored green synthesis and catalytic properties of gold nanocrystals. Spectrochimica Acta Part A 118:793-799

71. Panigrahi S, Basu S, Praharaj S, Pande J, Jana S, Pal A, Ghosh S-K, Pal T (2007) Synthesis and size-selective catalysis by supported gold nanoparticles: study on heterogeneous and homogeneous catalytic process. J Phys Chem C 111:4596-4605

72. AswathyAromal S, Philip D (2012) Green synthesis of gold nanoparticles using Trigonellafoenum-graecum and its size-dependent catalytic activity. Spectrochim Acta A 97:1-5

73. Vidhu V-K, Philip D (2014) Spectroscopic microscopic and catalytic properties of silver nanoparticles synthesized using Saraca indica flower. Spectrochim Acta A117:102-108

74. Bhakya S, Muthukrishnan S, Sukumaran M, Muthukumar M, Senthilkumar T, Rao M-V (2015) Catalytic degradation of organic dyes using synthesized silver nanoparticles: a green approach. J Bioremed Biodegrad 6:5

75. Mukwevho N, Elvis F, Waanders F, Kumar N, Ray S-S, Mbianda X-Y (2019) Photocatalytic activity of $\mathrm{Gd}_{2} \mathrm{O}_{2} \mathrm{CO}_{3}$ $\mathrm{ZnO} \cdot \mathrm{CuOnanocomposite} \mathrm{used} \mathrm{for} \mathrm{the} \mathrm{degradation} \mathrm{of} \mathrm{phenan-}$ threne. SN Appl Sci 1:10

76. Kolya H, Parthapratim M, Akhil P, Tripathy T (2015) Green synthesis of Silver nanoparticles with antimicrobial and azo dyes (Congo red) degradation properties using Amaranthus gangeticus Linn leaf extract. J Anal Sci Tech 6:3

77. Narayanan K-B, Park H-H, Han S-S (2015) Synthesis and characterisztion of biomatrixed-gold nanoparticles by the mushroom Flammulin velutipes and its heterogeneous catalytic potential. Chemosphere 141:169-175 